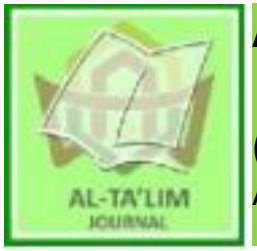

AL-TA'LIM JOURNAL, 27 (3), 2020, (227-235)

(Print ISSN 1410-7546 Online ISSN 2355-7893)

Available online at http://journal.tarbiyahiainib.ac.id/index.php/attalim

\title{
Colorful Online Learning Problem of Early Childhood Education During the Covid-19 Pandemic
}

Received: $01^{\text {th }}$ October 2020; Revised: $21^{\text {th }}$ October 2020; Accepted: $29^{\text {th }}$ Desember2020

Permalink/DOI: https://doi.org/10.15548/jt.v27i3.663

\section{Erni Munastiwi}

Universitas Islam Negeri Sunan Kalijaga, Yogyakarta, Indonesia

E-Mail: erni.munastiwi@uin-suka.ac.id

\begin{abstract}
This research aims to determine the various problems of online learning at the level of early childhood education units during the COVID-19 pandemic. As for the issues among them, teachers have not all mastered IT; students tend to get bored too long studying at home. Likewise, parents are not ready to change the role of teachers at home and the policies of the central government and local governments and other issues. This research uses a qualitative approach. Respondent consists of a teacher of 12 people and a parent of 25 people. Research location in Ponorogo Regency, East Java. The process of retrieving data using questionnaires through a google form. The results showed there were colorful problems, including 1) communication between educators, parents, and protégés, 2) the lack of costs for procurement of information technology facilities, and the price for online learning needs, 3) the right online learning method for early childhood. While the obstacles faced by parents are 1) mastery of material submitted to the child, 2) less growing the interest of the child, 3) internet network problems, 4) time accompanying the child to study online.
\end{abstract}

Keywords: Colorful online learning problem; early childhood; COVID-19 pandemic.

How to Cite: Munastiwi, E. (2020). Colorful Online Learning Problem of Early Childhood Education During the Covid-19 Pandemic. Al-Ta lim Journal, 27(3), 227-235. doi:https://doi.org/10.15548/jt.v27i3.663

\section{INTRODUCTION}

Early 2020 is a health crisis and a challenge for the world's population due to the covid-19 pandemic (Patricia, 2020). Not only health but the presence of the corona virus diseases (covid) outbreak has also managed to shake in sectors education (Baber, 2020). Around the world, schools are closed, and children are learning online with the help of their parents(Jæger \& Blaabæk, 2020) Coronavirus disease (Covid-19) is well known very quickly in its transmission. The disease attacks the human respiratory system, weakens the heart organs, and leads to death (Rothan \& Byrareddy, 2020). The amount of news that is quite horrendous is circulating in the community until this disease sounds so creepy to them. With these conditions, the government issued a policy of large-scale social restrictions on specific areas, social distancing, physical distancing, the lockdown of locations prone to COVID-19 spread. So with this condition, people are required to stay at home, work from home, study and worship from home whose purpose is to break the chain in the spread of the disease (Jamaludin, et al., 2020).

The government's policy in dealing with the coronavirus disease (Covid-19) caused panic and challenges in education. Due to face-to-face activities temporarily suspended (Mishra, Gupta, \& Shree, 2020). 
However, learning activities are still conducted online (Sadikin \& Hamidah, 2020). We are learning with online systems, using the immediate access that is the internet network that can bring up various types of learning interactions such as zoom applications, google classroom, teacher room, etc (Abdulkareem \& Eidan, 2020). With the application, it can connect students and teachers to carry out learning (Syarifudin, 2020).

Online learning applies to all levels of education, ranging from PAUD, kindergarten, elementary school, junior high school, high school/ vocational school, and higher education university. Education is a conscious effort made to promote the potential of students. Early childhood education is an education given from childbirth to six years (Hikmawati \& Munastiwi, 2018). So the importance of early education to form personality as well as character attached to the individual self. The range of early childhood is about 4-6 years, or experts call it the golden age, where the development of intelligence increases by up to $50 \%$ (Zaini, 2015). The primary education for early childhood starts at home. The habits of those closest to it become a significant influence on the formation of the character of the child. Besides, it is also supported by formal education in educational institutions to maximize the intelligence and personality of the child (Maragustam. 2018). Effective learning will score fun and meaningful experiences in the mind of the child. Learning while playing can hone a child's ability to solve a problem and provide a challenging experience. But conducive learning has not been realized through education using online systems. Students are less able to learn effectively from home, making online learning highly ineffective Due to minimal interaction, exploration, and physical activity (Owusu-Fordjour et al., 2020; Yeasmin et al., 2020). Also, it makes children more miserable and difficult to manage to study at home (Dong, Cao, \& Li, 2020). Teachers as a control center in learning still have many difficulties controlling the situation and various online learning. In quality PAUD learning activities that require teachers to be closer to students both physically and psychologically. Learning activities are because early childhood education non-formal through play and has no target of achieving academic achievement but more on optimizing children's development. Teachers, in practice, make a comfortable and safe learning environment for children.

In addition to the obstacles in creating practical learning situations, another impact is communication between teachers and students in teaching-learning activities that do not occur directly, efficiencies, and difficulties in maintaining academic integrity (Mukhtar, Javed, Arooj, \& Sethi, 2020), because between students and teachers limited by distance. The intertwining of learning communication only through the application is also not able to run optimally. Students are accustomed to face-to-face learning with educators and studying together with classmates (Ayu, Lestari, \& Gunawan, 2020). face-to-face in early childhood education has substantive grades to assist students in achieving success in learning. Because faceto-face activities make children more focused on the study, teachers can directly monitor physical, spiritual, and psychological development. Not only that, but teachers must also have the ability to know, understand and be able to use technology by the advancement of Science And Technology (Rothan \& Byrareddy, 2020), especially in the current conditions that require teachers to use applications in online learning that adjust the needs of the COVID-19 pandemic.

Face-to-face learning can generate motivation and a higher student learning spirit. COVID-19 pandemic hurts early childhood education because they are not used to learning effectively independently (Owusu-Fordjour et al., 2020). Thus, it dramatically impacts the psychosocial of children during the Covid-19 pandemic (Dubey et al., 2020). Therefore, online learning for early childhood is in desperate need of help from parents. Teachers should work with parents to make online learning a happy place during the current pandemic (Agustin et al., 2020). Online learning makes students unable to absorb the subject matter that is being delivered by the teacher. 
Learning with this system also has an impact on less effective learning, such as interference from the home environment, unreliable internet, inadequate communication between educators and learners, as well as a lack of experience to prepare online learning (Setiawan, 2020). With the provision of online learning that applies to all levels of education, especially PAUD, teachers must have exceptional and more creative skills to attract the attention and focus of the students. Based on some of the arguments presented above, the researchers focused on online learning of early childhood COVID-19 pandemic. The purpose of this research is to describe the constraints of teaching PAUD teachers during the pandemic COVID-19.

\section{METHOD}

The approach in this article uses a qualitative approach (Bachtiar, 2010). Data retrieval techniques using semi- Structure interviews and documentation related to the online learning problems of educators and parents - the process of retrieving data using instrument questions and documentation sent through a google form. The research subjects consisted of 12 teachers and 25 parents in the Ponorogo area, East Java. Research data analysis includes three sub-processes, namely data reduction, data display, and data verification. In contrast, the data validity test uses source triangulation. The general inductive analysis of interview data is systematically and logically compiled (Come, et al. 2014).

\section{RESULT AND DISCUSSION}

One of the impacts of Covid-19 in education is the dismissal of face-to-face teaching activities in classrooms that are replaced by online or online learning (Dhawan, 2020). The same is also for early childhood education. This form of learning activity for early childhood tends to be on learning while playing because playing, the child can explore to get to know the surrounding environment so that the lessons are more meaningful as a child (Astuti \& Munastiwi 2018). Learning while playing has a significant influence on the child's development. With the government's policy on rules for learning from home, it is required for educators to adapt to learning strategies that are by the application of online learning. There needs to be careful preparation and the ability to start online learning to run effectively and efficiently (Agustin et al., 2021).

The results found that in online learning planning, teachers often hold inperson meetings in school buildings because some teachers have limited internet access. Teachers also create weekly picket schedules. Thus, keeping the school building awake even if not used by learning. Early childhood educators are always required to have innovations and abilities that can develop children's creativity. But in online learning, early childhood educators experience some obstacles such as communication constraints between students, parents, and educators, constraints in learning methods, and constraints in the costs and technologies used. Specifically as follows:

\section{Communication Constraints Between Educators, Students, and Parents}

In education, the role of communication is very influential in the learning process. Communication between educators and students affects the learning process (Inayah, 2015). It is in this learning communication that there is an exchange of educational messages about learning whose purpose is none other than to develop the potential of students. Educators have a vital position in learning as communicators. Educators should be able to provide good communication for their children so that the materials provided are well received.

Online learning using gadget or laptop communication media is difficult for educators, especially early childhood educators, in delivering learning materials. Therefore, educators need to work with parents to help with online learning to run effectively. However, a survey of research conducted found that educators still have difficulty in equating the purpose of learning to the parents of students. Besides, educators also have a problem coordinating with 
students' parents because some parents do not know the picture of online learning in their implementation.

... It's hard to ask for help as a guardian to accompany their child during online learning because the guardian still does not understand how online learning is... (excerpt of the interview with NT mother)

... sometimes the parents of students do not want to give me a report of the child's activities at home as a teacher, so it is complicated to know the development of the student ... (excerpt of the interview with MD's mother)

... I called my parents to ask how good it was to keep the child going to study, but the parents of the students instead requested to be taken off the school because it was a waste of money to buy internet packages... (excerpt of the interview with DL mother)

These constraints prove that the lack of knowledge of students' parents on how to learn online. Besides, parents also think that online learning is just a waste of money to buy internet packages. Communication between educators and parents is not smooth, so it is also very influential in teaching educators to students. This problem can be minimized by deliberation between teachers and parents directly so that there is no misunderstanding about the process of implementing online learning. In practice, educators need to work with parents to succeed in online education. Thus. Parents occupy a critical position in guiding and directing children during home learning to replace the role of teachers in the school. Effective communication is key to learning success and maintaining psychology between teachers and parents (Jiao et al., 2020; Reddy \& Gupta, 2020)

\section{Constraints in Cost and Technology}

Some things that need attention in doing online learning is about the media used by one of them, namely gadgets. Research conducted by educators already has advanced tools, but not enough in supporting online learning.

... My phone is already an android if for chatting and browsing alone can still. But if you've received a lot of files, it's been let go... (excerpt of the interview with DA's mother)

... Very banked if use personal internet quota because the salary is not so much and the house there is no wifi, so the internet quota is also quickly exhausted (excerpt of the interview with sr mother)...

... My phone is already android, but I can't wait long staring at the phone screen due to the age factor. So I found it difficult (excerpt from the interview with mom sm)...

From emerging problems, online learning requires educators to get new gadgets more adequately. Educators complained about the rapid use of internet quotas due to online learning in Ponorogo City, East Java, using the WhatsApp app to make video calls.

It is also complained about by the parents of students whose students do not have sophisticated gadgets. Parents are also willing to sell their farm animals to buy new devices to support children's learning. However, some parents are also indifferent and do not want to know about it. Indifferent parents tend not to guide their children and ask that school be off only. Other obstacles faced by parents also include increasing the cost of purchasing internet data packages.

\section{Constraints in Learning Methods}

The application of the online learning process for early childhood education is so much of a concern for educators. From the results of the research conducted, early childhood educators in the Ponorogo area of East Java still have difficulty in determining the right learning methods for children. besides, educators still have difficulty determining relevant learning media for use. 
... the beginning of the set of online learning in the past, the teachers in this school were perplexed in arranging and determining what the exact method was like (excerpt of the interview with LT's mother)...

... I feel confused about how the right method for this early childhood if learning online because the little boy needs a lot of guidance in person (excerpt of the interview with $R P$ mother)...

In response to the problem described earlier, some early childhood education schools in Ponorogo have several solutions. From the results of the survey, the study said that educators much minimize the learning of the use of gadgets or other media because it is considered less able to run effectively. Online learning is only to provide students with work to do. Regarding the follow-up afterward, some schools implemented study groups and conducted the Home Visit process.

Study groups are created in each hamlet and gather in one place with three to four students. Based on the research of the home visit process becomes one of the appropriate solutions in monitoring student learning. Home Visit activities to see children's development. Besides, Home Visit assists parents in gaining knowledge of the child's form and learning goals (Nahdi et al., 2020). So with Home Visit, parents have an idea of children's learning activities. Then from the Home Visit process, the role of parents in accompanying the child to learn goes well so that parents can measure the child's abilities and guide him in learning.

The Home Visit process implemented in various schools in the Ponorogo City of East Java also facilitates parents in reporting children's daily activities directly to educators because remembering Home Visit is not done every day. They are thus making it easier for educators to assess students. With the application of the Home Visit process, educators are also easier to monitor the course of children's activities in learning. On the other hand, students are no longer depressed by the various tasks given by educators. Although Home Visit is not every day, students can learn and play with their study group friends even though only three to four children.

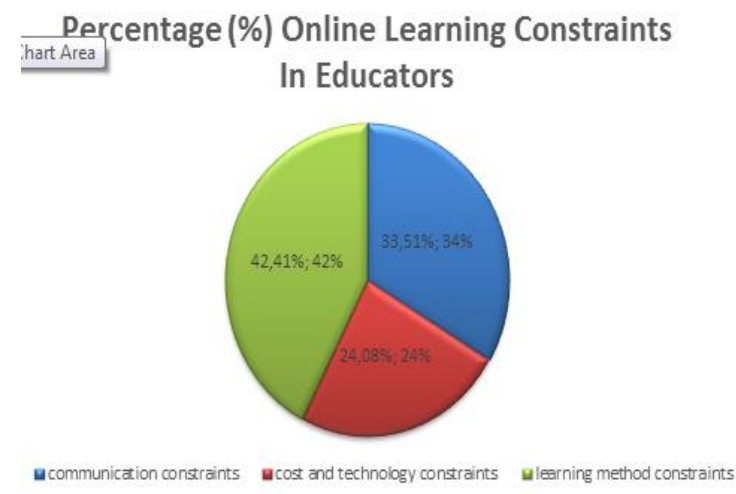

Figure 1: Research results in Online Learning Constraints on Educators

Based on the above percentage obtained, the level of communication constraints is $34 \%$. The cost and technology constraints rate are $24 \%$, level of regulation on learning methods is $42 \%$-the three barriers are experienced in general by early childhood educators in Ponorogo City, East Java.

The government's policy to close school activities and be diverted into online learning that requires schoolchildren from home raises some of the obstacles experienced by parents of students, especially for early childhood-the problems encountered by parents of students regarding the assistance of children in carrying out online learning. So many of the parents of students asked that the school be able to enter as usual. Here's a breakdown of parental constraints while accompanying a child in online learning:

\section{Constraints in Mastery of Material by Parents}

The results of the study show that the level of material mastery is the leading cause of online learning. Parents of students from different educational backgrounds influence their child's ability to guide during online learning. Parents complain about the difficulty of delivering material or even simply directing the child. It is also in line 
with previous research that says that parents of children often do not understand and even the lack of material knowledge provided by teachers to be channeled to their children, so parents cannot optimally deliver materials (Cahyati, 2020).

Parents who have extensive material knowledge will make it easier to run online learning. The child does not feel pressured by the parental explanation because the error in conveying the material will be fatal to the child's growth, in line with previous research that says that material understanding in parents is very influential in improving children's learning (Irhamna, 2016). Deliberation between educators and parents of students can be a solution to the constraints of the child's learning materials knowledge. Therefore, good communication will result in effective online learning.

\section{Obstacles in Dealing with Children's Learning Interests}

One form of success in parenting in empowering children to learn is to grow the child's interest. However, this is one of the obstacles in the running of online learning. The results of the study said that many parents are less able to grow the interest of children to be able to follow online learning, thus making the child less focused and lackluster in following the teachings. Therefore in line with previous research that says that academic success lies in children.

The most crucial strength before starting to learn is to cultivate a learning interest in children. The online learning process conducted at home makes the child and parent stressed (Araújo, Veloso, Souza, Azevedo, \& Tarro, 2020). It is also one of the triggers for children's low interest in online learning. Therefore, the importance of parents giving encouragement and motivation to the child to cultivate curiosity and provide an internal strength to the child. Emotional closeness to him is also necessary to foster the welfare of the child. Parents can explain and make deals with the child; parents can convince them to learn; parents can appreciate the child. This activity can create child interest. Therefore, the role of parents in accompanying the child to learn is the spearhead of the child's spirit to do online learning.

\section{Constraints in Collecting Media Gadgets and Internet Reach Problems}

The leading media for online learning is gadgets and internet access (Ayuni, 2021). The difficulty of parents in devices is one of the obstacles in the implementation of online learning. The results suggest that parents are a little confused when using learning apps like zoom and google classroom. Given that not all parents can use gadgets. Parents of students can only use the WhatsApp app. However, it can operate Whatsapp as an online learning medium (Almarzooq, 2020)

Communication between parents and teachers is very influential in the online learning process. Sometimes they also complain of inadequate internet networks and hinder online learning. Fast internet network is also one of the obstacles to online learning. That not all regions of Indonesia have affordable internet service, and it is not uncommon for slow internet (Kurniati, Nur Alfaeni, \& Andriani, 2020). The need to adapt learning methods according to local conditions so that students continue to learn even during the COVID-19 pandemic.

\section{Parental Constraints Not Enough Time To Accompany Children To Study Due to Work Demands}

Parents occupy an essential position during online learning at home - parents as facilitators who replace educators while at school must be ready in every way. Success in online learning is in parents, depending on how parents can accompany them during the online learning process. The results found that many parents still do not have time to accompany their children during the online learning process due to the demands of work, making it very detrimental for the child.

Thus, early childhood education schools have solutions; one of them is to make a home visit with a group of learning in a specific place that has been planned by the 
school. Each study group consisted of only three to four children. Although there are study groups, children's activities require assistance from parents. Considering early childhood still needs guidance to form a good and reliable character in later life.

\section{CONCLUSION RECOMMENDATION}

AND

Broadly the obstacles faced by early childhood educators in carrying out online learning are communication constraints between educators, parents, and learners, restrictions on the costs and technologies used, and regulations in learning methods that are appropriate for early childhood. Research findings of parental constraints include constraints in material mastery, growing child interest, conditions in the operation of gadgets, internet network problems, and time constraints of parents who cannot accompany their child during online learning. Recommendations for educators to be more creative and innovative in creating types of online learning activities. especially activities that can stimulate children's learning interests at home.

\section{REFERENCES}

Abdulkareem, T. A., \& Eidan, S. M. (2020). Online Learning for Higher Education Continuity (during COVID-19 Pandemic) The challenges, advantages, disadvantages and how to overcome: A Literature review. International Journal of Youth Economy, 4(2), 125.

Agustin M., Puspita DR., Nurinten, D., Nafiqoh, H. (2021). Tipikal Kendala Guru PAUD dalam Mengajar Pada Masa Pandemi Covid 19 dan Implikasinya. Jurnal Obsesi: Jurnal Pendidikan Anak Usia Dini. 5(1). 334345.

Almarzooq, Z., \& Kochtar, A. (2020). Virtual Learning During the COVID-19 Pandemic. Journal of The American College of Cardiology. 7 (20). 26352638.

Araújo, L. A. de, Veloso, C. F., Souza, M. de
C., Azevedo, J. M. C. de, \& Tarro, G. (2020). The potential impact of the COVID-19 pandemic on child growth and development: a systematic review. Jornal de Pediatria. 1-9.

Astuti, R., Munastiwi, E. 2018. Pendidikan Anak Usia Dini Berbasis Tauhid (Studi Kasus PAUD Ababil Kota Pangkalpinang). Al-Mudarris: Jurnal Ilmiah pedidikan Islam. 1(2). 1-19.

Ayu, P., Lestari, S., \& Gunawan, D. (2020). The Impact of Covid-19 Pandemic on Learning Implementation of Primary and Secondary School Levels. In Indonesian Journal of Elementary and Childhood Education (Vol. 1).

Ayuni, D., Marini, T., Fauziddin, M., Pahrul, Y. (2020). Kesiapan Guru TK Menghadapi Pembelajaran Masa Pandemi Covid-19. Jurnal Obsesi: Jurnal Pendidikan Anak Usia Dini. 5(1). 414-421.

Baber, H. (2020). Determinants of students' perceived learning outcome and satisfaction in online learning during the pandemic of COVID19. Journal of Education and E-Learning Research, 7(3), 285-292.

Bachtiar, SB. (2010). Menyajikan validasi data melalui triangulasi pada penelitian Kualitatif. Jurnal Teknologi Pendidikan. 10(1). 46-62.

Cahyati, N., \& Kusumah, R. (2020). Peran Orang Tua Dalam Menerapkan Pembelajaran Di Rumah. Jurnal Golden Age. Universitas Hamzanwadi. 04(1). 152- 159.

Come A., Bischof N., Epller.J M. (2014). Beyond Projection: Using Collaborative Visualization to Conduct Qualitative Interviews. Emerald Insight: Qualitative Research in Organization and Management, 9(2). 110-133.

Dhawan, S. (2020). Online Learning: A Panacea in the Time of COVID-19 Crisis. Journal of Educational Technology Systems, 49(1), 5-22.

Dong, C., Cao, S., \& Li, H. (2020). Young 
children's online learning during COVID-19 pandemic: Chinese parents' beliefs and attitudes. Children and Youth Services Review, 118, 105440.

Dubey, S., Biswas, P., Ghosh, R., Chatterjee, S., Dubey, M. J., Chatterjee, S., ... Lavie, C. J. (2020). Psychosocial impact of COVID-19. Diabetes and Metabolic Syndrome: Clinical Research and Reviews, 14(5), 779-788.

Hikmawati, N., Munastiwi, E. (2018). Manajemen Perpustakaan Dalam Menumbuhkan Minat Baca Anak. Golden Age: Jurnal Ilmiah Tumbuh Kembang Anak Usia dini. 3(3). 165-178.

Inayah, E. N. (2015). Peran komunikasi dalam interaksi guru dan siswa. AlTa'dib, 8(2), 150-167.

Irhamna. (2016). Analisis Kendala yang Dihadapi Orang Tua dalam Menanamkan Akhlak dan Kedisiplinan Belajar Siswa Madrasah Darussalam Kota Bengkulu. Pembelajaran Alquran Hadis di Man Pagar Alam. 57-65.

Jæger, M. M., \& Blaabæk, E. H. (2020). Inequality in learning opportunities during Covid-19: Evidence from library takeout. Research in Social Stratification and Mobility, 68, 100524.

Jamaluddin, D., Ratnasih, T., Gunawan, H., \& Paujiah, E. (2020). Pembelajaran daring masa pandemik Covid-19 pada calon guru: hambatan, solusi dan proyeksi. $L P 2 M$.

Jiao, W. Y., Wang, L. N., Liu, J., Fang, S. F., Jiao, F. Y., Pettoello-Mantovani, M., \& Somekh, E. (2020, June 1). Behavioral and Emotional Disorders in Children during the COVID-19 Epidemic. Journal of Pediatrics, Vol. 221, pp. 264-266.e1.

Kurniati, E., Nur Alfaeni, D. K., \& Andriani, F. (2020). Analisis Peran Orang Tua dalam Mendampingi Anak di Masa Pandemi Covid-19. Jurnal Obsesi: Jurnal Pendidikan Anak Usia Dini, 5(1), 241.
Lestari, P.A., Gunawan. (2020). The Impact of Covid-19 Pandemic on Learning Implementation of Primary and Secondary School Levels. Indonesian Journal of Elementary and Childhood Education. 1(2), 58-63.

Maragustam. (2018). Filsafat Pendidikan Islam Menuju Pembentukan Karakter. Yogyakarta: Pascasarjana UIN Sunan Kalijaga.

Mishra, D. L., Gupta, D. T., \& Shree, D. A. (2020). Online Teaching-Learning in Higher Education during Lockdown Period of COVID-19 Pandemic. International Journal of Educational Research Open, 100012.

Mukhtar, K., Javed, K., Arooj, M., \& Sethi, A. (2020). Advantages, limitations and recommendations for online learning during covid-19 pandemic era. Pakistan Journal of Medical Sciences, 36(COVID19-S4), S27-S31.

Nahdi, K., Ramdhani, S., Yuliatin, RR., Hadi, AY. (2021). Implementasi Pembelajaran Pada Masa Lockdown Bagi Lembaga PAUD di Kabupaten Lombok Timur. Jurnal Obsesi: Jurnal Pendidikan Anak Usia Dini. 5(1). 177186.

Owusu-Fordjour, C., Koomson, C. K., \& Hanson, D. (2020). The impact of Covid-19 on the learning-the perspective of the Ghanaian student. European Journal of Education Studies. 7,(3). 88-100.

Patricia, A. (2020). College Students' Use and Acceptance of Emergency Online Learning Due to COVID-19. International Journal of Educational Research Open, 100011.

Rothan, H. A., \& Byrareddy, S. N. (2020, May 1). The epidemiology and pathogenesis of coronavirus disease (COVID-19) outbreak. Journal of Autoimmunity, Vol. 109, p. 102433.

Reddy, Bv., \& Gupta, A. (2020). Importance of effective communication during COVID-19 infodemic. Journal of Family 
Medicine and Primary Care, 9(8), 3793.

Sadikin, A., \& Hamidah, A. (2020). Pembelajaran Daring di Tengah Wabah Covid-19. BIODIK, 6(2), 109-119.

Setiawan, A.R. (2020). Lembar Kegiatan Literasi Saintifik untuk Pembelajaran Jarak Jauh Topik Penyakit Coronavirus 2019 (COVID-19). Jurnal Edukatif. 2 (1), 28-37

Syarifudin, A. S. (2020). Impelementasi Pembelajaran Daring Untuk Meningkatkan Mutu Pendidikan Sebagai Dampak Diterapkannya Social
Distancing. Jurnal Pendidikan Bahasa Dan Sastra Indonesia Metalingua, 5(1), 31-34.

Yeasmin, S., Banik, R., Hossain, S., Hossain, M. N., Mahumud, R., Salma, N., \& Hossain, M. M. (2020). Impact of COVID-19 pandemic on the mental health of children in Bangladesh: A cross-sectional study. Children and Youth Services Review, 117, 105277.

Zaini, Ahmad. (2015). Bermain Sebagai Metode Pembelajaran Anak Usia dini. Thufula. 3(01). 118-134. 